\title{
Dissolved organic matter composition and bioavailability reflect ecosystem productivity in the Western Arctic Ocean
}

\author{
Y. Shen ${ }^{1}$, C. G. Fichot ${ }^{1}$, and R. Benner ${ }^{1,2}$ \\ ${ }^{1}$ Marine Science Program, University of South Carolina, Columbia, South Carolina 29208, USA \\ ${ }^{2}$ Department of Biological Sciences, University of South Carolina, Columbia, South Carolina 29208, USA \\ Correspondence to: Y. Shen (shen2@email.sc.edu)
}

Received: 15 June 2012 - Published in Biogeosciences Discuss.: 27 July 2012

Revised: 5 November 2012 - Accepted: 20 November 2012 - Published: 6 December 2012

\begin{abstract}
Dissolved organic carbon (DOC) and total dissolved amino acids (TDAA) were measured in high (Chukchi Sea) and low (Beaufort Sea) productivity regions of the western Arctic Ocean to investigate the composition and bioavailability of dissolved organic matter (DOM). Concentrations and DOC-normalized yields of TDAA in Chukchi surface waters were relatively high, indicating an accumulation of bioavailable DOM. High concentrations and yields of TDAA were also observed in the upper halocline of slope and basin waters, indicating off-shelf transport of bioavailable DOM from the Chukchi Sea. In contrast, concentrations and yields of TDAA in Beaufort surface waters were relatively low, indicting DOM was of limited bioavailability. Concentrations and yields of TDAA in the upper halocline of slope and basin waters were also low, suggesting the Beaufort is not a major source of bioavailable DOM to slope and basin waters. In shelf waters of both systems, elevated concentrations and yields of TDAA were often observed in waters with higher chlorophyll concentrations and productivity. Surface concentrations of DOC were similar $(p>0.05)$ in the two systems despite the contrasting productivity, but concentrations and yields of TDAA were significantly higher $(p<0.0001)$ in the Chukchi than in the Beaufort. Unlike bulk DOC, TDAA concentrations and yields reflect ecosystem productivity in the western Arctic. The occurrence of elevated bioavailable DOM concentrations in the Chukchi Sea implies an uncoupling between the biological production and utilization of DOM and has important implications for sustaining heterotrophic microbial growth and diversity in oligotrophic waters of the central Arctic basins.
\end{abstract}

\section{Introduction}

Two contrasting systems, the Chukchi and Beaufort Seas, occur adjacent to each other in the western Arctic Ocean. The Chukchi Sea is a large $\left(620 \times 10^{3} \mathrm{~km}^{2}\right)$ and shallow ( $\sim 80 \mathrm{~m}$ avg.) inflow shelf area that receives nutrient-rich $\mathrm{Pa}$ cific waters via Bering Strait, which support a very productive ecosystem (Jakobsson et al., 2004; Sakshaug, 2004; Grebmeier et al., 2006). In comparison, the Beaufort Sea is a narrow and small $\left(178 \times 10^{3} \mathrm{~km}^{2}\right)$ river-influenced interior shelf that is relatively deep ( $\sim 124 \mathrm{~m}$ avg.; Jakobsson et al., 2004). The major nutrient sources to the Beaufort shelf are the Mackenzie River and upwelling (Macdonald et al., 1987). Primary productivity is limited in regions of the Beaufort shelf due to the high water turbidity and stratification caused by coastal erosion and river runoff (Carmack and Wassmann, 2006).

The distinct shelf typology and nutrient supply lead to the contrasting productivity between the Chukchi and Beaufort Seas. Primary productivity in the Chukchi Sea parallels nutrient concentrations and increases from $30-90 \mathrm{~g} \mathrm{C} \mathrm{m}^{-2} \mathrm{yr}^{-1}$ in the northeast to $720 \mathrm{~g} \mathrm{C} \mathrm{m}^{-2} \mathrm{yr}^{-1}$ in the southwest (Walsh et al., 1989; Springer and McRoy, 1993; Cota et al., 1996; Hill and Cota, 2005). Areas associated with seasonal upwelling, such as Barrow Canyon, are typically more productive (e.g., $8 \mathrm{~g} \mathrm{C} \mathrm{m}^{-2} \mathrm{~d}^{-1}$ ) than adjacent waters (Hill and Cota, 2005). In contrast, primary productivity in the Beaufort Sea is relatively low (10-70 $\mathrm{g} \mathrm{C} \mathrm{m}^{-2} \mathrm{yr}^{-1}$ ) due to lower nutrient availability and reflects the strong influence from the Mackenzie River (Carmack et al., 2004; Sakshaug, 2004; Lavoie et al., 2009). Shelf waters are less productive within the river plume (e.g., $<10 \mathrm{~g} \mathrm{C} \mathrm{m}^{-2} \mathrm{yr}^{-1}$ ) as a result of limited light 
penetration and become more productive outside the plume (30-70 $\mathrm{g} \mathrm{C} \mathrm{m}^{-1} \mathrm{yr}^{-1}$; Sakshaug, 2004; Carmack and Wassmann, 2006). Relatively high primary production is observed in the eastern Beaufort Sea where the Cape Bathurst polynya forms during May-June at the entrance to the Amundsen Gulf. These open waters extend the phytoplankton growth season, resulting in elevated primary production (Arrigo and van Dijken, 2004; Brugel et al., 2009).

Off-shelf transport of organic matter from productive shelf waters is thought to be an important carbon source for heterotrophic metabolism in the interior Arctic basins (Walsh et al., 1989; Davis and Benner, 2005, 2007; Mathis et al., 2007). The disparity between a large metabolic demand for carbon in the basins and low concentrations of particulate organic carbon (POC) suggests the shelf-basin connection likely relies on dissolved organic carbon (DOC; Wheeler et al., 1997). The extent of this reliance, however, is largely determined by the concentrations and bioavailability of dissolved organic matter (DOM), which are likely to vary spatially and temporally along with ecosystem productivity. Exploring the role of DOM in the shelf-basin connection therefore requires the assessment of DOM bioavailability under varying productivity regimes.

DOM is often categorized into three pools of reactivity, labile, semi-labile and refractory, which have broadly defined turnover times of hours to weeks, months to years and centuries to millennia, respectively (Kirchman et al., 1993; Carlson and Ducklow, 1995). Labile DOM is often operationally defined using bioassay experiments, but this approach has limited utility for defining semi-labile and refractory DOM (Ogura, 1975; Søndergaard and Middleboe, 1995; Del Giorgio and Davis, 2002; Benner, 2003). The inherent biochemical properties of DOM shape its bioavailability, which in combination with environmental conditions and microbial community composition, determine the turnover time of labile and semi-labile DOM. Herein, we use amino acids as molecular indicators of the bioavailability of DOM (Benner, 2003). Amino acids are the building blocks of peptides and proteins, and they are abundant in plankton and planktonderived DOM (Lee et al., 2004; Davis and Benner, 2007). They are bioreactive components of labile and semi-labile DOM, making them good indicators of the bioavailability of DOM in aquatic systems (Amon et al., 2001; Davis and Benner, 2007; Davis et al., 2009).

High concentrations of bioavailable DOM, as indicated by high concentrations and DOC-normalized yields of total dissolved amino acids (TDAA), are observed in the Chukchi Sea (Davis and Benner, 2005, 2007). It is speculated that bioavailable DOM produced in the Chukchi shelf is entrained into the halocline of the Canadian Basin and fuels oxygen utilization there (Walsh et al., 1997; Davis and Benner, 2007). It is unclear whether a similar process is active in the Beaufort Sea due to a paucity of data for this region. In addition, despite the fact that the Chukchi Sea is more productive than the Beaufort Sea, differences in surface-water concentrations of DOC are not apparent (Davis and Benner, 2005; Guéguen et al., 2005; Mathis et al., 2005). In the present study, the concentrations of DOC and TDAA in the Chukchi and Beaufort Seas were compared to investigate the composition and bioavailability of DOM in these adjacent but quite different systems. Our results reveal that the contrasting productivity between the Chukchi and Beaufort Seas is reflected in DOM bioavailability, as indicated by the concentrations and yields of TDAA.

\section{Materials and methods}

\subsection{Study sites and sample collection}

The Chukchi and Beaufort Seas were surveyed during four summer cruises of three different Arctic projects. In 2002 (17 July-21 August) and 2004 (18 July-26 August), water samples from the Chukchi Sea and the adjacent Canada Basin were collected aboard the research vessel USCGC Healy, as part of the Western Arctic ShelfBasin Interactions (SBI) project (http://www.eol.ucar.edu/ projects/sbi/; Fig. 1). In 2008 (19 July-29 July), water samples were collected from the Mackenzie River plume, Beaufort Sea, and Amundsen Gulf on the CCGS Amundsen, as part of the Circumpolar Flaw Lead (CFL) program (http://web.mac.com/barber1818/iWeb/IPY-CFL/; Fig. 1). In 2009 (27 July-27 August), waters in the Mackenzie River plume, Beaufort Sea, and Canada Basin were sampled on the CCGS Amundsen as part of the Malina (MAL) program (http://malina.obs-vlfr.fr/; Fig. 1). Water samples from the four cruises were collected at various depths using Niskin bottles mounted on a rosette with a conductivitytemperature-depth (CTD) sensor. Samples were filtered through combusted $\left(450^{\circ} \mathrm{C}, 4 \mathrm{~h}\right) \mathrm{GF} / \mathrm{F}$ glass fiber filters and stored frozen $\left(-20^{\circ} \mathrm{C}\right)$ in $60 \mathrm{~mL}$ high-density polyethylene (HDPE) screw-cap bottles until analyses of DOC, total dissolved nitrogen (TDN), and TDAA were performed in the home laboratory. The HDPE bottles were soaked in $0.5 \mathrm{~mol} \mathrm{~L}^{-1}$ hydrochloric acid $(\mathrm{HCl})$ for $24 \mathrm{~h}$ and rinsed with Milli-Q UV-Plus water before cruises.

The broad spatial scale of sampling sites in this study covers a wide range of environments that vary in primary productivity. The SBI 2002 and 2004 cruises covered relatively productive waters of the Chukchi Sea, which receives nutrient-rich water from the Pacific Ocean, whereas the CFL 2008 and MAL 2009 cruises covered the less productive southern Beaufort Sea, which is influenced by runoff from the Mackenzie River. In this study, sampling regions were separated into shelf (bottom depth $\leq 100 \mathrm{~m}$, salinity $\geq 27.0$ ), slope $(100 \mathrm{~m}<$ bottom depth $\leq 1000 \mathrm{~m})$, and basin (bottom depth $>1000 \mathrm{~m}$ ) areas. In the slope and basin regions, surface water was defined as $0-80 \mathrm{~m}$ depth, which includes the chlorophyll maximum layer. The upper halocline in the slope 


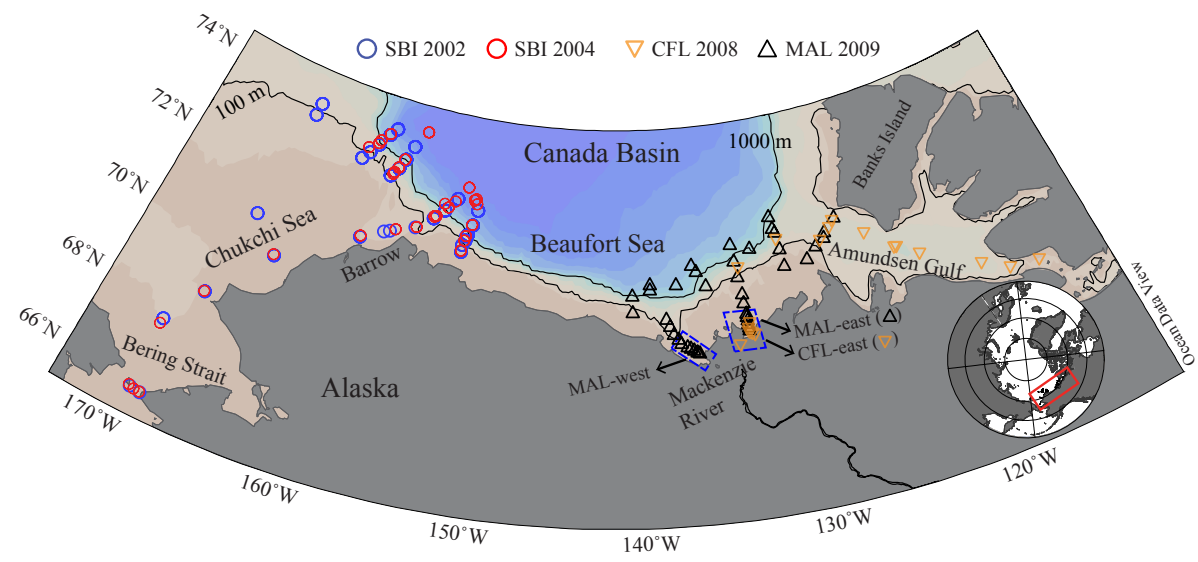

Fig. 1. Locations of sampling stations in the western Arctic Ocean. Four cruises were conducted during the summer and sampled the shelf, slope, and basin environments of the Chukchi and Beaufort Seas. Blue circles - SBI 2002; red circles - SBI 2004; brown inverse triangles CFL 2008; black triangles - MAL 2009. The Mackenzie River plume was surveyed during CFL 2008 (CFL-east) and MAL 2009 (MAL-west and MAL-east). The 100 and $1000 \mathrm{~m}$ isobaths are shown.

Table 1. Physicochemical characteristics in shelf, slope and basin waters of the Chukchi and Beaufort Seas*.

\begin{tabular}{|c|c|c|c|c|c|c|c|c|c|}
\hline Cruise & $\begin{array}{r}\text { Depth } \\
(\mathrm{m})\end{array}$ & $\begin{array}{r}\text { Temperature } \\
\left({ }^{\circ} \mathrm{C}\right)\end{array}$ & $\begin{array}{r}\text { Salinity } \\
(\mathrm{psu})\end{array}$ & $\begin{array}{r}\text { DOC } \\
\left(\mu \mathrm{mol} \mathrm{L} \mathrm{L}^{-1}\right)\end{array}$ & $\begin{array}{r}\text { TDN } \\
\left(\mu \mathrm{mol} \mathrm{L}^{-1}\right)\end{array}$ & $\begin{array}{r}\text { TDAA } \\
\left(\mathrm{nmol} \mathrm{L}^{-1}\right)\end{array}$ & $\begin{array}{r}\text { TDAA } \\
(\% \text { DOC })\end{array}$ & DI & $n$ \\
\hline \multicolumn{10}{|c|}{ Shelf $(0-80 \mathrm{~m})$} \\
\hline SBI 2002 & $24 \pm 11$ & $1.29 \pm 3.26$ & $31.17 \pm 1.41$ & $77 \pm 12$ & $8.0 \pm 4.5$ & $462 \pm 177$ & $1.70 \pm 0.66$ & $-0.20 \pm 0.80$ & 22 \\
\hline SBI 2004 & $26 \pm 16$ & $4.53 \pm 3.37$ & $31.40 \pm 0.89$ & $83 \pm 17$ & $7.9 \pm 4.4$ & $406 \pm 107$ & $1.58 \pm 0.43$ & $-0.50 \pm 0.54$ & 19 \\
\hline CFL 2008 & & & nd & & & & & nd & nd \\
\hline MAL 2009 & $19 \pm 16$ & $1.56 \pm 2.48$ & $29.95 \pm 1.67$ & $85 \pm 20$ & $6.1 \pm 1.9$ & $289 \pm 138$ & $1.17 \pm 0.57$ & $0.45 \pm 0.90$ & 18 \\
\hline \multicolumn{10}{|c|}{ Slope-basin (surface: $0-80 \mathrm{~m}$ ) } \\
\hline SBI 2002 & $39 \pm 16$ & $-1.32 \pm 0.41$ & $31.40 \pm 1.17$ & $76 \pm 6$ & $10.1 \pm 5.8$ & $319 \pm 61$ & $1.12 \pm 0.21$ & $-0.90 \pm 0.61$ & 24 \\
\hline SBI 2004 & $35 \pm 17$ & $-0.10 \pm 1.77$ & $31.24 \pm 1.12$ & $73 \pm 5$ & $7.7 \pm 4.0$ & $402 \pm 165$ & $1.84 \pm 0.79$ & $-1.17 \pm 1.09$ & 44 \\
\hline CFL 2008 & $5 \pm 1$ & $6.20 \pm 1.87$ & $29.01 \pm 1.25$ & $74 \pm 5$ & $5.1 \pm 0.6$ & $225 \pm 14$ & $1.00 \pm 0.07$ & $0.49 \pm 1.13$ & 12 \\
\hline MAL 2009 & $37 \pm 26$ & $0.09 \pm 2.17$ & $29.69 \pm 3.51$ & $78 \pm 25$ & $5.8 \pm 2.0$ & $192 \pm 47$ & $0.80 \pm 0.14$ & $-0.44 \pm 0.41$ & 37 \\
\hline \multicolumn{10}{|c|}{ Slope-basin (upper halocline: $80-180 \mathrm{~m}, 32.0-33.9 \mathrm{psu}$ ) } \\
\hline SBI 2002 & $131 \pm 29$ & $-1.53 \pm 0.17$ & $33.22 \pm 0.41$ & $69 \pm 3$ & $18.6 \pm 2.1$ & $243 \pm 41$ & $0.92 \pm 0.17$ & $-1.58 \pm 0.42$ & 23 \\
\hline SBI 2004 & $129 \pm 23$ & $-1.50 \pm 0.15$ & $33.09 \pm 0.35$ & $70 \pm 5$ & $17.2 \pm 1.4$ & $344 \pm 119$ & $1.64 \pm 0.66$ & $-1.35 \pm 1.43$ & 20 \\
\hline CFL 2008 & $112 \pm 30$ & $-1.39 \pm 0.12$ & $33.20 \pm 0.33$ & $66 \pm 4$ & $16.9 \pm 2.8$ & $177 \pm 19$ & $0.84 \pm 0.06$ & $1.08 \pm 1.15$ & 9 \\
\hline MAL 2009 & $136 \pm 26$ & $-1.38 \pm 0.06$ & $32.93 \pm 0.39$ & $64 \pm 3$ & $16.2 \pm 1.6$ & $150 \pm 18$ & $0.75 \pm 0.11$ & $-0.63 \pm 0.46$ & 13 \\
\hline
\end{tabular}

*Samples were collected during four summer cruises (July-August). Definitions: Shelf (bottom depth $\leq 100 \mathrm{~m}$, salinity $\geq 27.0$ ); Slope (bottom depth $100-1000 \mathrm{~m}$ ); Basin (bottom depth $>1000 \mathrm{~m}$ ).

Surface water in the slope and basin was defined as 0-80 m depth. Upper halocline water in the slope and basin was defined based on depth and salinity ( $80-180 \mathrm{~m}$, $32.0 \leq$ salinity $\leq 33.9$ ). Data are reported as averages \pm standard deviations.

nd: not determined.

and basin was delimited by depth $(80-180 \mathrm{~m})$ and salinity $(32.0 \leq$ salinity $\leq 33.9$; Table 1$)$.

\subsection{Chemical analyses}

Aliquots of filtered (Whatman GF/F; 0.7- $\mu \mathrm{m}$ nominal poresize) water samples were acidified to $\mathrm{pH} \approx 2$ with $2 \mathrm{~mol} \mathrm{~L}^{-1}$ $\mathrm{HCl}$ for DOC and TDN analyses. DOC and TDN were measured using high temperature combustion and a Shimadzu TOC-V analyzer equipped with an inline chemiluminescence nitrogen detector (Shimadzu TN-1; Davis and Benner, 2005). Milli-Q UV-Plus water (blank) and reference standards (deep Sargasso Sea water obtained from the University of Miami) were injected every 6th sample to check the accuracy of the measurements (Benner and Strom, 1993). Blanks were negligible and values for reference standards were within $5 \%$ of reported values.

Aliquots of filtered water samples were hydrolyzed for analysis of TDAA using an Agilent High Performance Liquid Chromatography (HPLC) system equipped 
with a fluorescence detector (Excitation: $330 \mathrm{~nm}$; Emission: $450 \mathrm{~nm}$ ). Water samples were dried with pure nitrogen gas and hydrolyzed using a vapor phase method with $6 \mathrm{~mol} \mathrm{~L}^{-1} \mathrm{HCl}$ at $150^{\circ} \mathrm{C}$ for $32.5 \mathrm{~min}$. After neutralization, TDAA were measured as $o$-phthaldialdehyde (OPA) derivatives following the method of Kaiser and Benner (2005). The separation of compounds was performed on a Licrosphere RP18 $(4.6 \times 150 \mathrm{~mm}, 5 \mu \mathrm{m}$ particles $)$ or a Zorbax SB-C18 $(4.6 \times 150 \mathrm{~mm}, 3.5 \mu \mathrm{m}$ particles $)$ column. Eighteen amino acids were included in the analysis: asparagine + aspartic acid (Asx), glutamine + glutamic acid (Glx), serine (Ser), histidine (His), glycine (Gly), threonine (Thr), $\beta$-alanine $(\beta$-Ala), arginine (Arg), alanine (Ala), $\gamma$-aminobutyric acid $(\gamma$-Aba), tyrosine (Tyr), valine (Val), phenylalanine (Phe), isoleucine (Ile), leucine (Leu), and lysine (Lys).

DOC-normalized yields of TDAA (\% DOC) were calculated as the percentage of DOC measured as amino acids. The degradation index (DI) is a diagenetic indicator derived from a principal component analysis of protein amino acid compositions (Dauwe and Middelburg, 1998). In this study, the DI was calculated following the method of Dauwe et al. (1999), as modified by Kaiser and Benner (2009) for application to DOM. In general, positive DI values indicate recently produced DOM and declining values indicate more diagenetically altered DOM (Davis et al., 2009).

\subsection{Bioavailable DOM}

Three categories of DOM biological lability (labile, semilabile, and refractory) were defined by Davis and Benner (2007) based on DOC-normalized yields of TDAA. Refractory DOM refers to deep-water DOM $(>1000 \mathrm{~m})$ that has an average TDAA yield of $0.70 \%$ DOC in the Arctic Ocean and is resistant to biological utilization over long timescales (decades to millennia; Davis and Benner, 2007). In this study, DOM with TDAA yields $>0.70 \%$ DOC is considered bioavailable, and increasing yields of TDAA reflect increasing concentrations of bioavailable DOM.

\subsection{Statistical analyses}

Statistical analyses were performed with SPSS 20.0 (IBM Statistical Package for the Social Sciences Inc.). The significance of correlations between variables was determined using the Spearman's rho test (two-tailed, $\alpha=0.05$ ) because the data were not normally distributed. Statistical differences were assessed using the Mann-Whitney U test (two-tailed, $\alpha=0.05$ ) because of unequal group sizes and non-normal distribution of the data.

\section{Results}

\subsection{Concentrations and distribution of DOM in the Mackenzie River plume}

Small boat surveys of surface waters in the Mackenzie River plume (salinity: 0.15-29.90) were conducted during the CFL 2008 and MAL 2009 cruises (Fig. 1). Concentrations of DOC ranged from 106 to $458 \mu \mathrm{mol} \mathrm{L}^{-1}$, with the highest value occurring in the Mackenzie River (salinity: 0.15). The concentrations of DOC across the salinity gradient followed a similar conservative mixing trend during the two cruises $\left(R^{2}=0.9260, p<0.001, n=19\right.$; Fig. 2a). Non-conservative mixing across the salinity gradient was observed in concentrations of TDAA, and sources of TDAA were evident at mid salinities (6.5-15.5; Fig. 2b). DOC-normalized yields of TDAA were minimal in the river $(0.42 \%$ DOC) and progressively increased with salinity (Fig. 2c). The two highest yields (1.20 and $1.32 \%$ DOC) were observed at mid-salinity locations with elevated TDAA concentrations, indicating a plankton source. Yields of TDAA were generally higher at mid salinities (6.5-15.5) during CFL 2008 than MAL 2009 (Fig. 2c).

\subsection{Concentrations and composition of DOM in the Chukchi and Beaufort Seas}

DOC concentrations in Chukchi and Beaufort shelf waters ranged from 59 to $146 \mu \mathrm{mol} \mathrm{L}^{-1}$ (avg.: $81 \mu \mathrm{mol} \mathrm{L}{ }^{-1}$ ) and showed considerable variability at all depths (Fig. 3a). In comparison, DOC concentrations were lower in slope and basin waters $\left(41-201 \mu \mathrm{mol} \mathrm{L}^{-1}\right.$; avg.: $67 \mu \mathrm{mol} \mathrm{L}^{-1}$; Fig. 3a-c; Table 1). Concentration ranges and depth trends of DOC were similar among cruises, with elevated concentrations occurring in near surface waters and decreasing concentrations with depth (Fig. 3b-c).

TDAA concentrations in shelf, slope, and basin waters were more variable than DOC concentrations and ranged from 70 to $983 \mathrm{nmol} \mathrm{L}^{-1}$ (avg.: $311 \mathrm{nmol} \mathrm{L}^{-1}$; Fig. 4ac). TDAA concentrations were substantially higher in the Chukchi Sea (SBI 2002, 2004; avg.: $323 \mathrm{nmol} \mathrm{L}^{-1}$ ) than in the Beaufort Sea (CFL 2008, MAL 2009; avg.: $186 \mathrm{nmol} \mathrm{L}^{-1}$ ). Peak concentrations of TDAA in shelf waters were typically found at $10-30 \mathrm{~m}$ (Fig. 4a). Concentrations of TDAA generally declined from shelf waters to slope and basin waters (Fig. 4a-c; Table 1). Elevated concentrations of TDAA were found at greater depths $(\sim 200 \mathrm{~m})$ in slope and basin waters during SBI 2002 and 2004 (Fig. 4b-c). Concentrations of TDAA in slope waters during CFL 2008 (avg.: $185 \mathrm{nmol} \mathrm{L}^{-1}$ ) were significantly higher than those at similar depths during MAL 2009 (avg.: $161 \mathrm{nmol} \mathrm{L}^{-1} ; p<0.05$; Fig. 4b).

DOC-normalized yields of TDAA were much higher in the Chukchi Sea (0.39-4.23\% DOC, avg.: $1.41 \%$ DOC) compared with the Beaufort Sea (0.47-3.29\% DOC, avg.: 

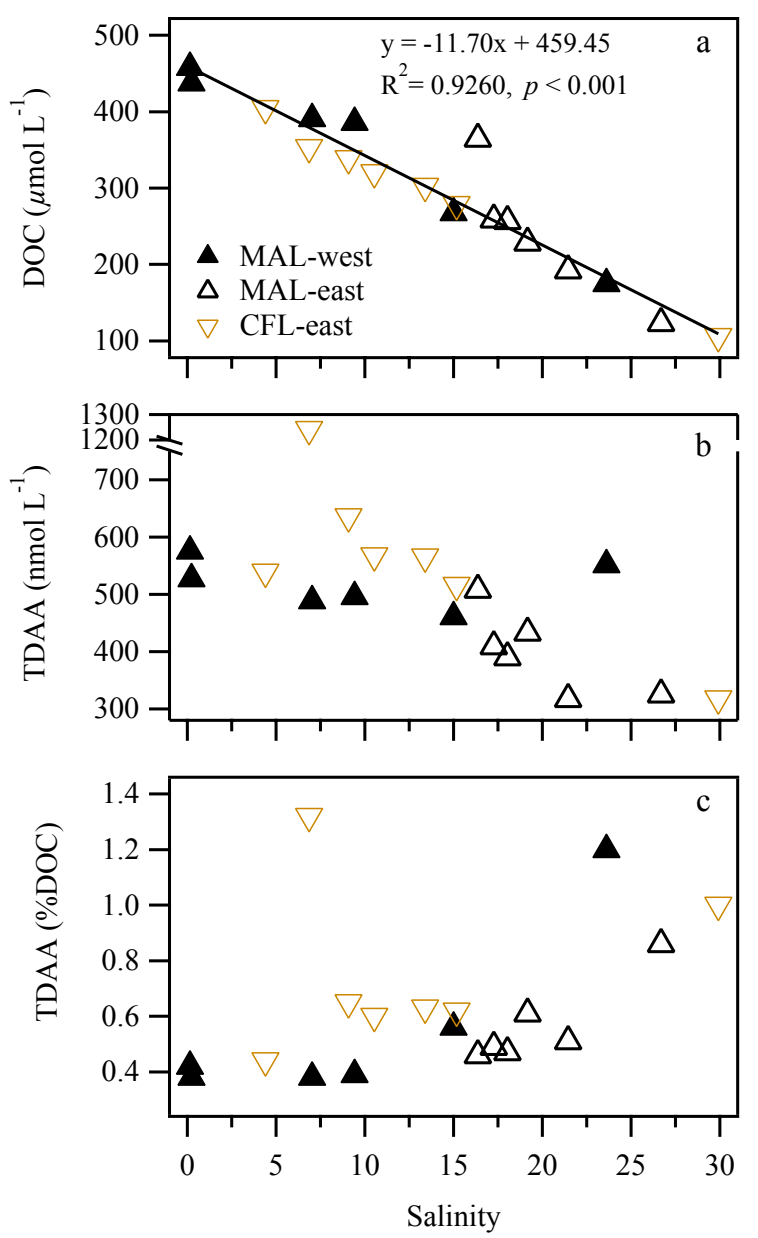

Fig. 2. Mixing patterns of DOM in the Mackenzie River plume. Distributions of (a) dissolved organic carbon (DOC), (b) total dissolved amino acids (TDAA), and (c) yields of TDAA (\% DOC) across the salinity gradient.

$0.84 \%$ DOC) (Fig. 5a-c). Maximal TDAA yields in shelf waters were found at $10-30 \mathrm{~m}$ (Fig. 5a). Yields of TDAA in slope and basin waters were particularly high in the upper $200 \mathrm{~m}$ during SBI 2004 and sometimes exceeded those in shelf waters (Fig. 5b-c). Yields of TDAA in slope waters during CFL 2008 (avg.: $0.88 \%$ DOC) were significantly higher than those at similar depths during MAL 2009 (avg.: $0.76 \%$ DOC; $p<0.001$; Fig. 5b).

Average amino acid degradation index (DI) values for the four cruises ranged from -1.58 to 1.08 (Table 1). During SBI 2002, 2004, and MAL 2009, DI values decreased from shelf waters to slope-basin surface waters, and with depth (Table 1). An opposite trend was observed during CFL 2008. In general, DI values were lower in the Chukchi Sea (SBI 2002, 2004) than in the Beaufort Sea (CFL 2008, MAL 2009) (Table 1). The variable DI values reflect amino acid compositional heterogeneity, which is influenced by source as well as diagenetic alterations. It appears source plays an impor- tant role in shaping DI values in these margin waters, which can have high and variable contributions of riverine DOM. The DI values for Mackenzie River DOM in 2008 and 2009, 1.34 and -0.37 , respectively, were very different indicating large variability in TDAA composition in riverine DOM. In contrast, the TDAA yields for Mackenzie River DOM in 2008 and 2009, 0.44 and $0.38 \%$ DOC, respectively, indicating minimal variability in TDAA yields in riverine DOM. Correlations between DI values and TDAA yields were quite variable among cruises (SBI 2002: $r=0.9064, p<0.001$; SBI 2004: $r=0.4694, p<0.001$; CFL 2008: $r=-0.2537$, $p=0.2945$; MAL 2009: $r=0.6838, p<0.001$ ), and it appears the influence of riverine DOM on DI values contributes to the weak correlation between DI and TDAA yield during the CFL cruise in 2008. Based on these observations, TDAA yields were considered better indicators of DOM bioavailability than DI values. In addition, bioassay experiments with a variety of substrates in waters from the Chukchi Sea concluded DI values are not reliable indicators of labile DOM (Davis et al., 2009).

\subsection{Statistical comparisons of DOM in the Chukchi and Beaufort Seas}

\subsubsection{Spatial and temporal variations of DOM in the Chukchi and Beaufort Seas}

The SBI 2002 and 2004 data were combined to represent the Chukchi Sea region, and the CFL 2008 and MAL 2009 data were combined to represent the Beaufort Sea region. In both regions, average concentrations of DOC and TDAA, and TDAA yields generally decreased from shelf waters to slopebasin surface waters, with a greater gradient occurring in the Beaufort Sea (Fig. 6a-c). One exception was that yields of TDAA in Chukchi shelf and slope-basin surface waters were quite similar ( $\sim 1.6 \%$ DOC; Fig. $6 c)$. Significant differences in DOC concentrations and TDAA yields between shelf waters and slope-basin surface waters were found in the Beaufort Sea $(p<0.01)$ but not in the Chukchi Sea $(p>0.1$; Table 2; Fig. 6a, c). Differences in TDAA concentrations were highly significant among shelf waters, slope-basin surface waters, and slope-basin upper halocline waters $(p<0.01$; Table 2; Fig. 6b). DOC and TDAA concentrations and TDAA yields in the upper halocline of both regions were substantially lower than those in shelf waters and slope-basin surface waters (Table 2; Fig. 6a-c).

Interannual variation of DOM concentrations and composition in the Chukchi Sea was examined by comparing data from SBI 2002 with data from SBI 2004. In shelf waters, none of the three parameters were significantly different between 2002 and 2004 ( $p>0.2$; Fig. 7a-c). Differences were significant in slope-basin surface waters, where DOC concentrations were significantly higher in $2002(p<0.05$; Fig. 7a) and concentrations and yields of TDAA were substantially higher in 2004 (concentration: $p=0.0585$, yield: 


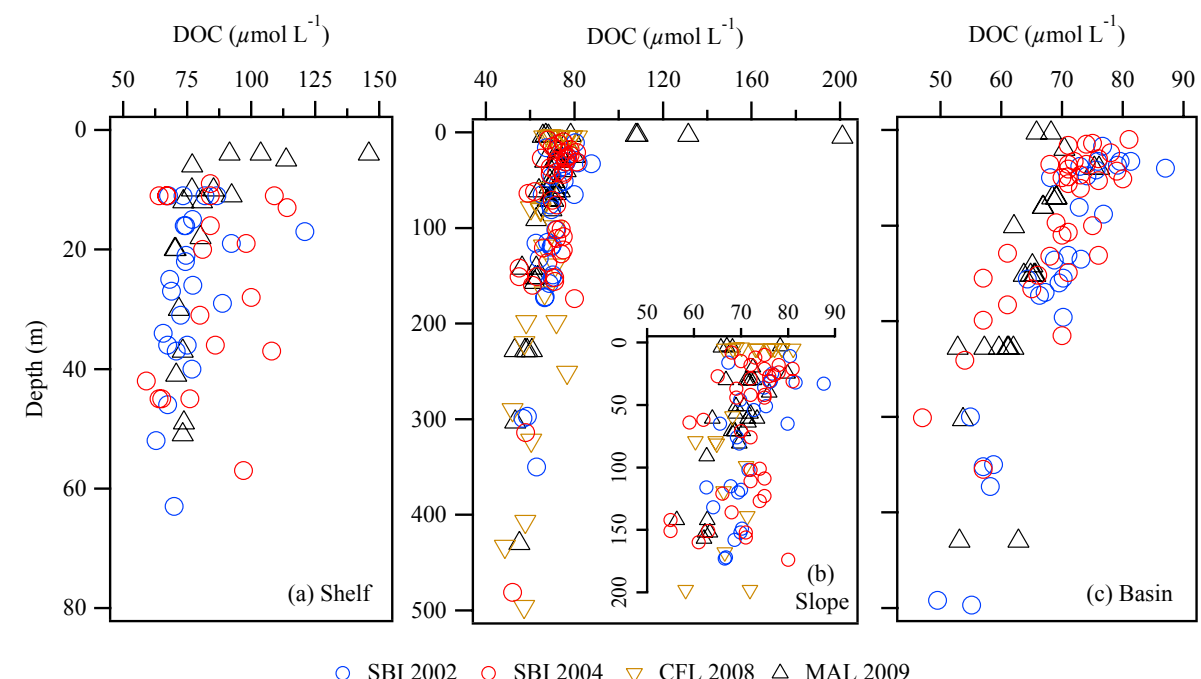

Fig. 3. Concentrations of dissolved organic carbon (DOC) in (a) shelf, (b) slope, and (c) basin waters of the Chukchi Sea (SBI 2002, SBI 2004) and Beaufort Sea (CFL 2008, MAL 2009).

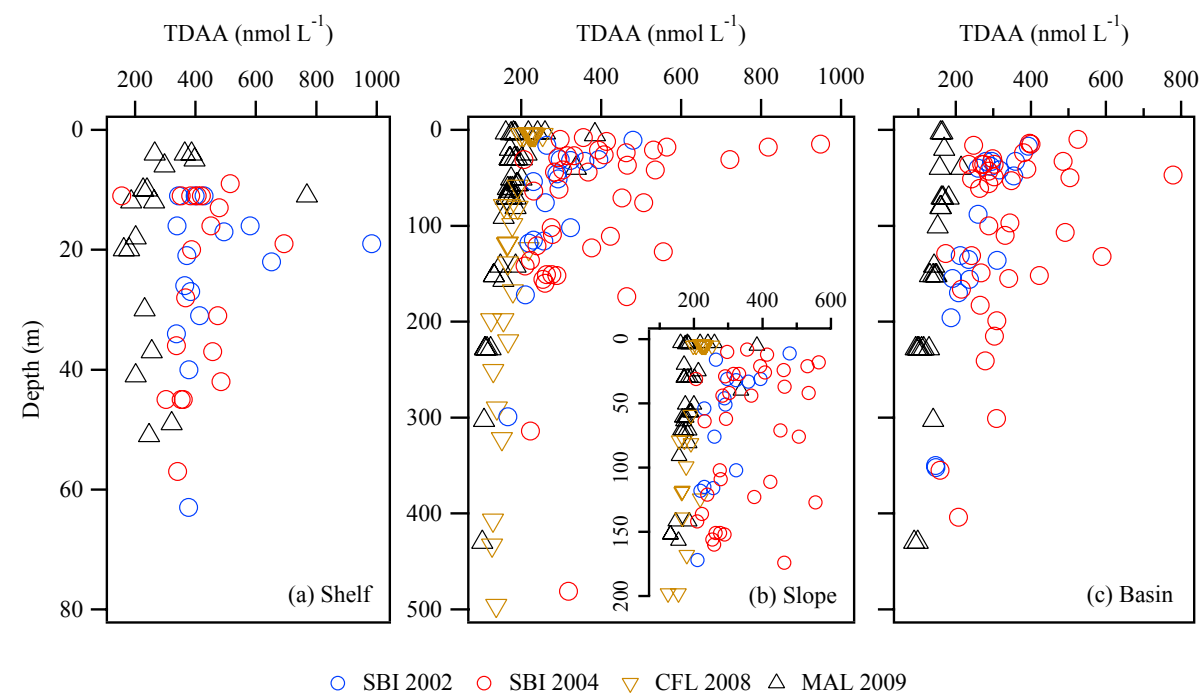

Fig. 4. Concentrations of total dissolved amino acids (TDAA) in (a) shelf, (b) slope, and (c) basin waters of the Chukchi Sea (SBI 2002, SBI 2004) and Beaufort Sea (CFL 2008, MAL 2009).

$p<0.0001$; Fig. $7 \mathrm{~b}-\mathrm{c})$. In contrast to DOC $(p=0.3028$; Fig. 7a), TDAA concentrations and yields in the upper halocline were significantly higher in 2004 than in 2002 $(p<0.01$; Fig. 7b-c). In 2002, average DOC and TDAA concentrations and TDAA yields decreased from shelf to slopebasin waters (Fig. 7a-c). In 2004, however, elevated concentrations and yields of TDAA were observed in both slopebasin surface and upper halocline waters (Fig. 7b-c), and average yields of TDAA were even higher in slope-basin surface and upper halocline waters than in shelf waters (Fig. 7c).

\subsubsection{Comparisons of DOM between the Chukchi and Beaufort Seas}

Average DOC concentrations in both shelf waters and slopebasin surface waters were slightly higher in the Beaufort Sea than in the Chukchi Sea (Fig. 6a), but not significantly different (shelf waters: $p>0.4$; slope-basin surface waters: $p>0.05$; Table 3). Significantly higher DOC concentrations were observed in upper halocline waters in the Chukchi compared with the Beaufort ( $p<0.0001$; Table 3; Fig. 6a). Concentrations and yields of TDAA in shelf waters were significantly higher $(\sim 1.5$-fold $)$ in the Chukchi than in the Beaufort $(p<0.0001$; Table 3; Fig. 6b-c). The differences 


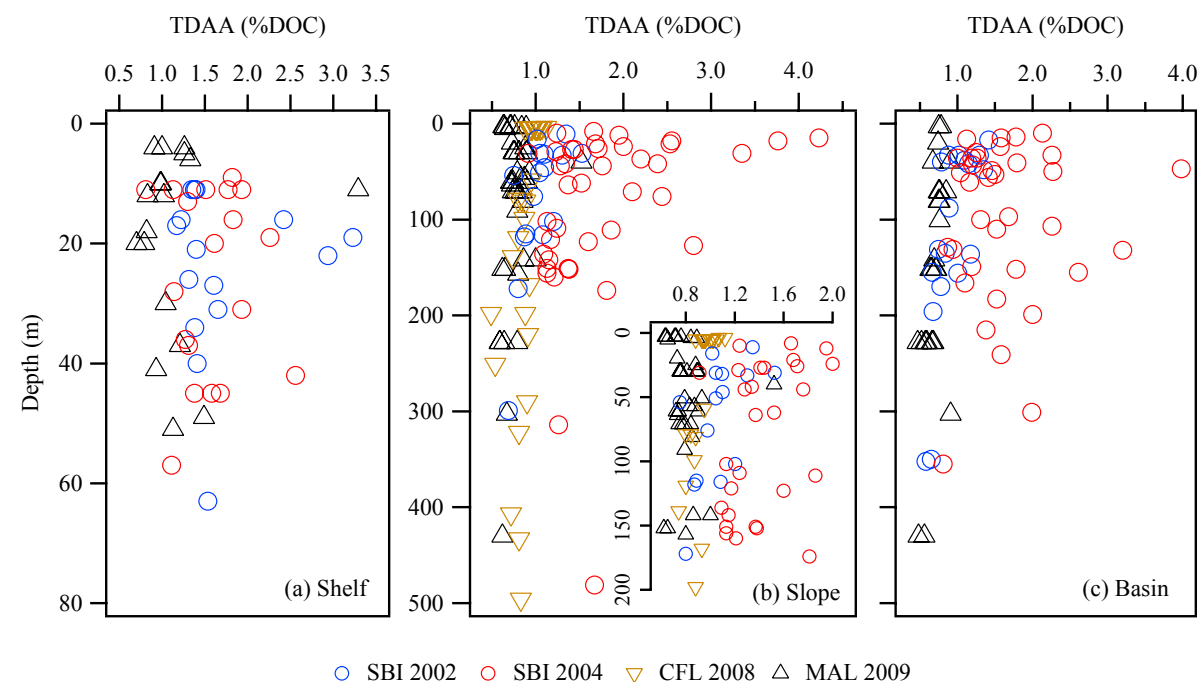

Fig. 5. DOC-normalized yields of total dissolved amino acids in (a) shelf, (b) slope, and (c) basin waters of the Chukchi Sea (SBI 2002, SBI 2004) and Beaufort Sea (CFL 2008, MAL 2009).

Table 2. Statistical comparisons of the concentrations of DOC and TDAA, and TDAA yields in the Chukchi and Beaufort Seas (MannWhitney U test).

\begin{tabular}{lrrr}
\hline Chukchi Sea & DOC $\left(\mu \mathrm{mol} \mathrm{L}^{-1}\right)$ & TDAA $\left(\mathrm{nmol} \mathrm{L}^{-1}\right)$ & TDAA $(\% \mathrm{DOC})$ \\
\hline Shelf vs. Slope-basin surface & $p=0.1408$ & $p<0.01$ & $p=0.3678$ \\
Shelf vs. Slope-basin upper halocline & $p<0.001$ & $p<0.0001$ & $p<0.01$ \\
Slope-basin (surface vs. upper halocline) & $p<0.0001$ & $p<0.01$ & $p<0.05$ \\
\hline Beaufort Sea & & & \\
\hline Shelf vs. Slope-basin surface & $p<0.01$ & $p<0.0001$ & $p<0.001$ \\
Shelf vs. Slope-basin upper halocline & $p<0.0001$ & $p<0.0001$ & $p<0.0001$ \\
Slope-basin (surface vs. upper halocline) & $p<0.0001$ & $p<0.0001$ & $p=0.0842$ \\
\hline
\end{tabular}

in concentrations and yields of TDAA between the two regions were more pronounced in slope-basin surface and upper halocline waters, with the values in the Chukchi Sea almost double those in the Beaufort Sea $(p<0.0001$; Table 3; Fig. 6b-c).

\section{Discussion}

\subsection{Concentrations and bioavailability of DOM in the Chukchi Sea}

Surface concentrations of DOC and TDAA in the Chukchi Sea were spatially variable and generally corresponded with chlorophyll-a concentrations and primary productivity (Davis and Benner, 2005; Hill and Cota, 2005; Kirchman et al., 2009a). Concentrations of DOC and TDAA decreased by $\sim 10 \%$ from shelf to slope-basin surface waters, and primary production also decreased from shelf to basin waters (Kirchman et al., 2009a). DOC-normalized yields of TDAA displayed minor spatial variations in shelf and slope-basin surface waters. The yields $(\sim 1.6 \%$ DOC $)$ were more than 2-fold greater than those in refractory DOM $(0.70 \%$ DOC; Davis and Benner, 2007), indicating a substantial supply of bioavailable DOM in surface waters of the Chukchi Sea. Maximal concentrations and yields of TDAA were observed at depths of 10-30 $\mathrm{m}$ where chlorophyll concentrations and primary production were also maximal in summer (Cota et al., 1996; Hill and Cota, 2005). This subsurface maximum was not observed for DOC concentrations. In comparison, concentrations of DOC and TDAA and yields of TDAA were significantly lower in the upper halocline $(p<0.01)$, but TDAA yields (1.38\% DOC) were greater than those of semilabile and refractory DOM (1.1 and $0.70 \%$ DOC, respectively; Davis and Benner, 2007). This indicates that although there was a substantial drawdown of bioavailable DOM below the euphotic zone, concentrations of bioavailable DOM remained relatively high in these waters.

The seasonal variability of bioavailable DOM in the Chukchi Sea was previously described by Davis and Benner $(2005,2007)$. Here, we further discuss the interannual 

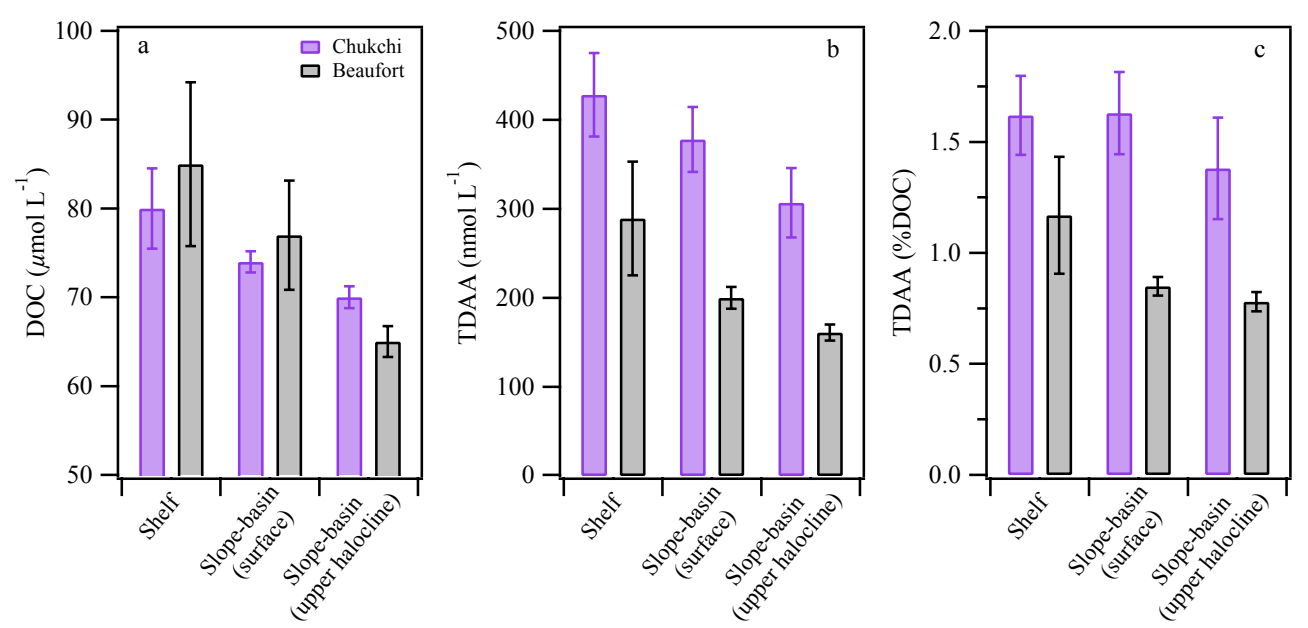

Fig. 6. Spatial variability of average concentrations of (a) dissolved organic carbon (DOC) and (b) total dissolved amino acids (TDAA), and (c) yields of TDAA in shelf, slope, and basin waters of the Chukchi and Beaufort Seas. Error bars represent two times the standard error.
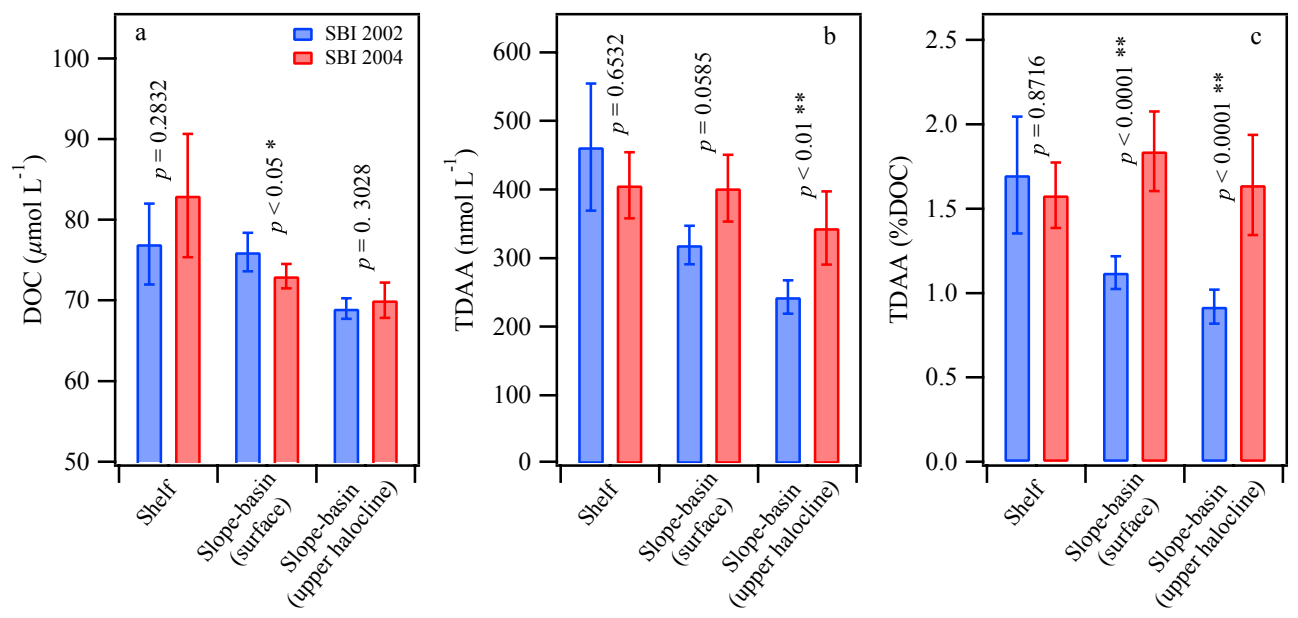

Fig. 7. Temporal comparisons of average concentrations of (a) dissolved organic carbon (DOC) and (b) total dissolved amino acids (TDAA), and (c) yields of TDAA in shelf, slope, and basin waters between SBI 2002 and 2004. Error bars represent two times the standard error. Significant $(p<0.05)$ and highly significant $(p<0.01)$ differences are marked with one and two asterisks, respectively.

variations of bioavailable DOM in different Chukchi regions. Concentrations of DOC and TDAA and yields of TDAA in shelf waters were high in the summers of 2002 and 2004 and were not significantly different between the two years $(p>0.2)$, indicating bioavailable DOM in shelf waters was relatively abundant and displayed small interannual variations. Concentrations and yields of TDAA decreased by over $30 \%$ from shelf to slope-basin surface waters in 2002. In contrast, in 2004 concentrations of TDAA in slope-basin surface waters remained high and the TDAA yields were even higher than those in shelf waters (1.84 vs. $1.58 \%$ DOC). Summer primary productivity in $2004\left(0.62 \mathrm{~g} \mathrm{C} \mathrm{m}^{-2} \mathrm{~d}^{-1}\right)$ was $\sim 2.5$ times higher than that in $2002\left(0.24 \mathrm{~g} \mathrm{C} \mathrm{m}^{-2} \mathrm{~d}^{-1}\right)$, but the highest production in 2004 occurred in shelf waters rather than in slope-basin waters (Kirchman et al., 2009a). The observations of higher primary production in shelf wa- ters and greater DOM bioavailability in slope-basin surface waters suggest a rapid off-shelf transport of bioavailable DOM in 2004. Concentrations and yields of TDAA in upper halocline waters were significantly higher in 2004 than in $2002(p<0.0001)$. In 2004, the average yield of TDAA in upper halocline waters $(1.64 \%$ DOC) was very similar to that of shelf waters (1.58\% DOC), thereby suggesting a source of shelf-produced labile DOM (Davis and Benner, 2007). The off-shelf transport of bioavailable DOM, however, was not apparent in 2002. These comparisons exhibit irregular interannual variability of bioavailable DOM in different Chukchi regions, as controlled by both biological and physical processes. 
Table 3. Comparisons of the concentrations of DOC and TDAA, and TDAA yields in the Chukchi and Beaufort Seas* (Mann-Whitney $U$ test).

\begin{tabular}{|c|c|c|c|c|c|c|}
\hline & \multicolumn{2}{|c|}{$\operatorname{DOC}\left(\mu \mathrm{mol} \mathrm{L}^{-1}\right)$} & \multicolumn{2}{|c|}{ TDAA $\left(\mathrm{nmol} \mathrm{L}^{-1}\right)$} & \multicolumn{2}{|c|}{ TDAA (\% DOC) } \\
\hline & Chukchi & Beaufort & Chukchi & Beaufort & Chukchi & Beaufort \\
\hline Shelf & $\begin{array}{r}80 \pm 15 \\
\quad(p=\end{array}$ & $\begin{array}{l}85 \pm 20 \\
4338)\end{array}$ & \multicolumn{2}{|c|}{$(p<0.0001)$} & $\begin{array}{r}1.62 \pm 0.53 \\
(p<\end{array}$ & $\begin{array}{l}1.17 \pm 0.57 \\
0001)\end{array}$ \\
\hline Slope-basin (surface) & \multicolumn{2}{|c|}{$(p=0.0570)$} & \multicolumn{2}{|c|}{$\begin{array}{c}3 / 8 \pm 14 / \quad 200 \pm 44 \\
(p<0.0001)\end{array}$} & \multicolumn{2}{|c|}{$\begin{array}{c}1.63 \pm 0.74 \quad 0.85 \pm 0.15 \\
(p<0.0001)\end{array}$} \\
\hline Slope-basin (upper halocline) & $\begin{array}{r}70 \pm 4 \\
(p<\end{array}$ & $\begin{array}{l}65 \pm 4 \\
0001)\end{array}$ & $\begin{array}{r}307 \pm 109 \\
\quad(p<0\end{array}$ & $\begin{array}{l}161 \pm 22 \\
0001)\end{array}$ & $\begin{array}{r}1.38 \pm 0.64 \\
(p<\end{array}$ & $\begin{array}{l}0.78 \pm 0.10 \\
.0001)\end{array}$ \\
\hline
\end{tabular}

*SBI 2002 and 2004 were combined to represent the Chukchi Sea region, whereas CFL 2008 and MAL 2009 were combined to represent the Beaufort Sea region. Data are reported as the average \pm standard deviation, with the p-value in parentheses.

\subsection{Concentrations and bioavailability of DOM in the Beaufort Sea}

Concentrations of DOC in the Mackenzie River plume ranged from $458 \mu \mathrm{mol} \mathrm{L}^{-1}$ in the river to $106 \mu \mathrm{mol} \mathrm{L}{ }^{-1}$ at a salinity of 29.9 and exhibited fairly conservative mixing across the salinity gradient in 2008 and 2009, as observed previously (Emmerton et al., 2008) and in other Arctic river plumes (Cauwet and Sidorov, 1996; Kattner et al., 1999; Amon, 2004). Desorption from sediments and plankton productivity can be major sources of DOM in river plumes (Macdonald et al., 1998; Benner and Opsahl, 2001; Dagg et al., 2004), whereas flocculation, bio- and photo-degradation can be important sinks of DOM (Chin-Leo and Benner, 1992; Uher et al., 2001; Bélanger et al., 2006; Garneau et al., 2006). Concentrations and yields of TDAA in the Mackenzie River plume were more variable across the salinity gradient, with elevated concentrations and yields of TDAA at mid salinities indicating a plankton source of bioavailable DOM. However, compared to river plumes at lower latitudes (e.g., the Mississippi River plume; Dagg et al., 2004), primary production, production of bioavailable DOM, and microbial processes in the Mackenzie River plume are relatively low (Retamal et al., 2007; Emmerton et al., 2008; Retamal et al., 2008).

Relatively high concentrations of DOC were observed in regions of the Beaufort shelf and reflected the influence of the Mackenzie River. Riverine input of nutrients supported patches of elevated primary production (Raimbault et al., unpublished data) and elevated concentrations and yields of TDAA in shelf waters, but generally low nutrient concentrations together with stratification of shelf waters during the summer typically resulted in the formation of a chlorophyll and productivity maximum at $\sim 30 \mathrm{~m}$ (Carmack et al., 2004; Lavoie et al., 2009; Raimbault et al., unpublished data). This pattern is reflected in elevated concentrations and yields of TDAA in subsurface waters. Bacterial production was strongly correlated with TDAA concentrations in the Beaufort Sea (Ortega-Retuerta et al., 2012), demonstrating amino acids are reliable indicators of bioavailable DOM. DOC and TDAA concentrations and yields of TDAA decreased rapidly (by $9 \%, 31 \%$, and $27 \%$, respectively) from shelf to slopebasin surface waters, as conditions became more oligotrophic due to the extensive sea ice cover in the summer of 2009. The low levels of primary production were reflected in low concentrations $\left(200 \mathrm{nmol} \mathrm{L}^{-1}\right)$ and yields $(0.85 \% \mathrm{DOC})$ of TDAA during this study. Concentrations of DOC and TDAA were lowest in upper halocline waters, and the off-shelf subsidy of bioavailable DOM was not apparent. Yields of TDAA in the upper halocline $(0.78 \%$ DOC $)$ were comparable to values in refractory DOM $(0.70 \%$ DOC), indicating DOM in these waters is resistant to biodegradation.

Heterogeneous distributions of bioavailable DOM in the Beaufort Sea were apparent from comparisons of the Amundsen Gulf (CFL 2008) and the southeastern Beaufort Sea (MAL 2009). Concentrations $(p<0.05)$ and yields $(p<0.001)$ of TDAA were significantly higher in the Amundsen Gulf than in the southeastern Beaufort Sea, but there was no significant difference $(p=0.4294)$ in DOC concentrations between the two regions. These higher TDAA concentrations are likely attributable to higher primary productivity $\left(0.28 \mathrm{~g} \mathrm{C} \mathrm{m}^{-2} \mathrm{~d}^{-1}\right)$ in the Amundsen Gulf than in the southeastern Beaufort region $\left(0.07 \mathrm{~g} \mathrm{C} \mathrm{m}^{-2} \mathrm{~d}^{-1}\right)$ at the time of sampling (Sallon et al., 2011; Raimbault et al., unpublished data). Although the observed variability of DOM and productivity can also be due to differences in sampling years (2008 vs. 2009), higher primary production in the Cape Bathurst polynya (52-175 $\mathrm{g} \mathrm{C} \mathrm{m}^{-2} \mathrm{yr}^{-1}$ ) than in the rest of the Beaufort Sea (including the Mackenzie shelf) is a well recognized feature in the Amundsen Gulf (Arrigo and van Dijken, 2004; Brugel et al., 2009; Forest et al., 2011). In addition to the release of bioavailable DOM from plankton, bacterial degradation of particulate organic matter and zooplankton activities provide additional sources of bioavailable DOM in the Amundsen Gulf (Juul-Pedersen et al., 2010; Forest et al., 2011; Kellogg et al., 2011). The elevated 
concentrations and yields of TDAA in the Amundsen Gulf are consistent with the higher productivity in this region.

Interannual variability of DOM in the Beaufort Sea is difficult to address given our limited data, but areas covering similar salinity ranges in the Mackenzie River plume and some shelf and slope waters were sampled during CFL 2008 and MAL 2009. Comparisons among these regions indicated higher TDAA concentrations and yields in 2008 than in 2009, with negligible differences in DOC concentrations. Strong seasonal forcing governs biological productivity in the Beaufort Sea such that interannual variability in DOM is not unexpected, but we anticipate less temporal variability in the Beaufort than in the Chukchi. Previous field and remote sensing analyses indicate less pronounced interannual variations in phytoplankton biomass and production in the Beaufort Sea as compared with the Chukchi Sea (Arrigo and van Dijken, 2004; Brugel et al., 2009).

\subsection{Comparisons of bioavailable DOM between the Chukchi and Beaufort Seas}

It is important to explore how the contrasting productivity between the Chukchi and Beaufort Seas influences the concentrations and bioavailability of DOM in the two systems. Primary productivity in the Chukchi Sea (e.g., 30$720 \mathrm{~g} \mathrm{C} \mathrm{m}^{-2} \mathrm{yr}^{-1}$; Springer and McRoy, 1993; Cota et al., 1996; Kirchman et al., 2009a) is typically much higher than that in the Beaufort Sea (e.g., $12-28 \mathrm{~g} \mathrm{C} \mathrm{m}^{-2} \mathrm{yr}^{-1}$; Carmack et al., 2004; Brugel et al., 2009; Lavoie et al., 2009). Given the higher primary productivity, higher rates of DOM production and consumption through the microbial loop are expected in the Chukchi Sea. However, DOC concentrations in shelf and slope-basin surface waters were not significantly different between the Chukchi and Beaufort Seas. Slightly higher concentrations of DOC were often observed in the Beaufort Sea, apparently due to the influence of the Mackenzie River. The difference in primary productivity between the two regions was not reflected in the concentrations of bulk DOC.

In contrast to the similarities in DOC concentrations, TDAA concentrations in Chukchi shelf and slope-basin surface waters were $50-90 \%$ higher $(p<0.0001)$ than those in the Beaufort Sea. The bioavailability of DOM, as indicated by yields of TDAA, was also significantly $(p<0.0001)$ higher (by $90 \%$ ) in surface waters of the Chukchi Sea compared with those of the Beaufort Sea. Primary productivity in the Chukchi Sea during the sampling periods ranged from 0.24 to $0.62 \mathrm{~g} \mathrm{C} \mathrm{m}^{-2} \mathrm{~d}^{-1}$ and resulted in the production of DOM that is rich in amino acids and is of high bioavailability (Davis and Benner, 2005, 2007; Kirchman et al., 2009a). In comparison, primary productivity in nutrient-poor waters of the Beaufort Sea was low (0.03-0.45 $\mathrm{g} \mathrm{C} \mathrm{m}^{-2} \mathrm{~d}^{-1}$; Sallon et al., 2011; Raimbault et al., unpublished data) and led to lower concentrations of bioavailable DOM. The contrasting productivity of the Chukchi and Beaufort Seas appears to be reflected in the abundance and distribution of TDAA.

Significantly higher DOC and TDAA concentrations and yields of TDAA were evident in the upper halocline of the Chukchi region in comparison to the Beaufort. High concentrations and yields of TDAA were observed to depths of $200 \mathrm{~m}$ in the Chukchi region and appear to be derived from shelf and slope waters in the region (Davis and Benner, 2007). A variety of physical processes likely contribute to the transport of bioavailable DOM into upper halocline waters, including the injection of dense Pacific Winter Water and mesoscale eddies that form along the shelf break (Manley and Hunkins, 1985; Mathis et al., 2007; Spall et al., 2008). Additional sources of bioavailable DOM in halocline waters include the direct release from plankton, grazing, viral lysis, and release from sinking particles and sediments (Strom et al., 1997; Cooper et al., 2005; Azam and Malfatti, 2007). In contrast, these indicators of bioavailable DOM were not observed in the upper halocline of the Beaufort Sea. Bioavailable DOM is important for sustaining the heterotrophic community in the upper halocline (Wallace et al., 1987; Cota et al., 1996). Concentrations of bioavailable DOM in the upper halocline of the Chukchi region were higher than those in the Beaufort, thereby revealing the important role of the Chukchi Sea in providing bioavailable DOM to low-productivity basins of the Arctic Ocean. This strong shelf-basin interaction was not apparent in the Beaufort Sea.

The observed net accumulation of bioavailable DOM during the summer in the Chukchi Sea and adjacent slopebasin waters indicates an uncoupling between the biological production and utilization of DOM. The direct cause(s) of this uncoupling is unknown, but it suggests DOM remineralization in the microbial loop is depressed. Temperature, availability of labile substrates and nutrient concentrations play important roles in regulating bacterial growth and the functioning of the microbial loop (Pomeroy and Deibel, 1986; Thingstad et al., 1997; Kirchman et al., 2009b; OrtegaRetuerta et al., 2012). Additions of relatively high concentrations of bioavailable substrates to water collected from the Chukchi Sea can result in delayed responses from the microbial community that can persist for days to weeks before utilization occurs (Davis et al., 2009). This slow response to bioavailable substrates could also indicate deficiencies in the metabolic diversity of the microbial community. In any case, the net accumulation of bioavailable DOM in the Chukchi Sea and other productive shelves, such as the Barents Sea, could be critical for sustaining heterotrophic microbial communities and microbial diversity in the highly oligotrophic waters of the central Arctic basins. 
Acknowledgements. We gratefully acknowledge the officers, crew and scientists of the USCGC Healy and CCGS Amundsen for logistical support during the four summer expeditions. We thank Karl Kaiser for providing guidance for amino acid analyses and Simon Bélanger for space on the CFL cruise. This is a contribution of the Shelf-Basin Interaction (SBI), Circumpolar Flaw Lead (CFL), and Malina programs. The Malina Program was funded by ANR (Agence nationale de la recherche), INSU-CNRS (Institut national des sciences de l'univers - Centre national de la recherche scientifique), CNES (Centre national d'études spatiales) and ESA (European Space Agency). The authors were supported by grants from the US National Science Foundation (0125301 and 0713915).

Edited by: M. Babin

\section{References}

Amon, R.: The role of dissolved organic matter for the organic carbon cycle in the Arctic Ocean, in: The organic carbon cycle in the Arctic Ocean, edited by: Stein, R. and Macdonald, R., SpringerVerlag, Berlin, 83-99, 2004.

Amon, R. M. W., Fitznar, H. P., and Benner, R.: Linkages among the bioreactivity, chemical composition, and diagenetic state of marine dissolved organic matter, Limnol. Oceanogr., 46, 287297, 2001.

Arrigo, K. R. and van Dijken, G. L.: Annual cycles of sea ice and phytoplankton in Cape Bathurst polynya, southeastern Beaufort Sea, Canadian Arctic, Geophys. Res. Lett., 31, L08304, doi:10.1029/2003GL018978, 2004.

Azam, F. and Malfatti, F.: Microbial structuring of marine ecosystems, Nat. Rev. Microbiol., 5, 782-791, 2007.

Bélanger, S., Xie, H. X., Krotkov, N., Larouche, P., Vincent, W. F., and Babin, M.: Photomineralization of terrigenous dissolved organic matter in Arctic coastal waters from 1979 to 2003: Interannual variability and implications of climate change, Global Biogeochem. Cy., 20, GB4005, doi:10.1029/2006gb002708, 2006.

Benner, R.: Molecular indicators of the bioavailability of dissolved organic matter, in: Aquatic ecosystems: Interactivity of dissolved organic matter, edited by: Findlay, S. and Sinsabaugh, R., Elsevier, 121-137, 2003.

Benner, R. and Opsahl, S.: Molecular indicators of the sources and transformations of dissolved organic matter in the Mississippi river plume, Org. Geochem., 32, 597-611, 2001.

Benner, R. and Strom, M.: A critical evaluation of the analytical blank associated with DOC measurements by high-temperature catalytic oxidation, Mar. Chem., 41, 153-160, 1993.

Brugel, S., Nozais, C., Poulin, M., Tremblay, J. É., Miller, L. A., Simpson, K. G., Gratton, Y., and Demers, S.: Phytoplankton biomass and production in the southeastern Beaufort Sea in autumn 2002 and 2003, Mar. Ecol.-Prog. Ser., 377, 63-77, 2009.

Carlson, C. A. and Ducklow, H. W.: Dissolved organic carbon in the upper ocean of the central equatorial Pacific Ocean, 1992: Daily and finescale vertical variations, Deep-Sea Res. Part II, 42, 639-656, doi:10.1016/0967-0645(95)00023-J, 1995.

Carmack, E. and Wassmann, P.: Food webs and physical-biological coupling on pan-Arctic shelves: Unifying concepts and comprehensive perspectives, Prog. Oceanogr., 71, 446-477, 2006.

Carmack, E. C., Macdonald, R. W., and Jasper, S.: Phytoplankton productivity on the Canadian Shelf of the Beaufort Sea, Mar.
Ecol.-Prog. Ser., 277, 37-50, 2004.

Cauwet, G. and Sidorov, I.: The biogeochemistry of Lena River: Organic carbon and nutrients distribution, Mar. Chem., 53, 211227, 1996.

Chin-Leo, G. and Benner, R.: Enhanced bacterioplankton production and respiration at intermediate salinities in the Mississippi River plume, Mar. Ecol.-Prog. Ser., 87, 87-103, 1992.

Cooper, L. W., Benner, R., McClelland, J. W., Peterson, B. J., Holmes, R. M., Raymond, P. A., Hansell, D. A., Grebmeier, J. M., and Codispoti, L. A.: Linkages among runoff, dissolved organic carbon, and the stable oxygen isotope composition of seawater and other water mass indicators in the Arctic Ocean, J. Geophys. Res., 110, G02013, doi:10.1029/2005jg000031, 2005.

Cota, G., Pomeroy, L., Harrison, W., Jones, E., Peters, F., Sheldon, W., and Weingartner, T.: Nutrients, primary production and microbial heterotrophy in the southeastern Chukchi Sea: Arctic summer nutrient depletion and heterotrophy, Mar. Ecol.-Prog. Ser., 135, 247-258, 1996.

Dagg, M., Benner, R., Lohrenz, S., and Lawrence, D.: Transformation of dissolved and particulate materials on continental shelves influenced by large rivers: plume processes, Cont. Shelf Res., 24, 833-858, 2004.

Dauwe, B. and Middelburg, J. J.: Amino acids and hexosamines as indicators of organic matter degradation state in North Sea sediments, Limnol. Oceanogr., 43, 782-798, 1998.

Dauwe, B., Middelburg, J., Herman, P., and Heip, C.: Linking diagenetic alteration of amino acids and bulk organic matter reactivity, Limnol. Oceanogr., 44, 1809-1814, 1999.

Davis, J. and Benner, R.: Seasonal trends in the abundance, composition and bioavailability of particulate and dissolved organic matter in the Chukchi/Beaufort Seas and western Canada Basin, Deep-Sea Res. Part II, 52, 3396-3410, 2005.

Davis, J. and Benner, R.: Quantitative estimates of labile and semilabile dissolved organic carbon in the western Arctic Ocean: A molecular approach, Limnol. Oceanogr., 52, 2434-2444, 2007.

Davis, J., Kaiser, K., and Benner, R.: Amino acid and amino sugar yields and compositions as indicators of dissolved organic matter diagenesis, Org. Geochem., 40, 343-352, 2009.

Del Giorgio, P. and Davis, J.: Patterns in dissolved organic matter lability and consumption across aquatic ecosystems, Aquatic ecosystems: interactivity of dissolved organic matter, Academic Press, San Diego, CA, 399-424, 2002.

Emmerton, C. A., Lesack, L. F. W., and Vincent, W. F.: Nutrient and organic matter patterns across the Mackenzie River, estuary and shelf during the seasonal recession of sea-ice, J. Mar. Syst., 74, 741-755, 2008.

Forest, A., Tremblay, J.-É., Gratton, Y., Martin, J., Gagnon, J., Darnis, G., Sampei, M., Fortier, L., Ardyna, M., Gosselin, M., Hattori, H., Nguyen, D., Maranger, R., Vaqué, D., Marrasé, C., Pedrós-Alió, C., Sallon, A., Michel, C., Kellogg, C., Deming, J., Shadwick, E., Thomas, H., Link, H., Archambault, P., and Piepenburg, D.: Biogenic carbon flows through the planktonic food web of the Amundsen Gulf (Arctic Ocean): A synthesis of field measurements and inverse modeling analyses, Prog. Oceanogr., 91, 410-436, 2011.

Garneau, M. Ė., Vincent, W. F., Alonso-Sáez, L., Gratton, Y., and Lovejoy, C.: Prokaryotic community structure and heterotrophic production in a river-influenced coastal arctic ecosystem, Aquat. Microb. Ecol., 42, 27-40, 2006. 
Grebmeier, J. M., Cooper, L. W., Feder, H. M., and Sirenko, B. I.: Ecosystem dynamics of the Pacific-influenced northern Bering and Chukchi seas in the Amerasian Arctic, Prog. Oceanogr., 71, 331-361, 2006.

Guéguen, C., Guo, L., and Tanaka, N.: Distributions and characteristics of colored dissolved organic matter in the western Arctic Ocean, Cont. Shelf Res., 25, 1195-1207, 2005.

Hill, V. and Cota, G.: Spatial patterns of primary production on the shelf, slope and basin of the Western Arctic in 2002, Deep-Sea Res. Part II, 52, 3344-3354, 2005.

Jakobsson, M., Grantz, A., Kristoffersen, Y., and Macnab, R.: The Arctic Ocean: Boundary conditions and background information, in: The organic carbon cycle in the Arctic Ocean, Springer, edited by: Stein, R. and Macdonald, R., Springer-Verlag, Berlin, 1-32, 2004.

Juul-Pedersen, T., Michel, C., and Gosselin, M.: Sinking export of particulate organic material from the euphotic zone in the eastern Beaufort Sea, Mar. Ecol.-Prog. Ser., 410, 55-70, 2010.

Kaiser, K. and Benner, R.: Hydrolysis-induced racemization of amino acids, Limnol. Oceanogr.-Meth., 3, 318-325, 2005.

Kaiser, K. and Benner, R.: Biochemical composition and size distribution of organic matter at the Pacific and Atlantic time-series stations, Mar. Chem., 113, 63-77, 2009.

Kattner, G., Lobbes, J. M., Fitznar, H. P., Engbrodt, R., Nöthig, E. M., and Lara, R. J.: Tracing dissolved organic substances and nutrients from the Lena River through Laptev Sea (Arctic), Mar. Chem., 65, 25-39, 1999.

Kellogg, C. T. E., Carpenter, S. D., Renfro, A. A., Sallon, A., Michel, C., Cochran, J. K., and Deming, J. W.: Evidence for microbial attenuation of particle flux in the Amundsen Gulf and Beaufort Sea: elevated hydrolytic enzyme activity on sinking aggregates, Polar Biol., 34, 2007-2023, 2011.

Kirchman, D. L., Hill, V., Cottrell, M. T., Gradinger, R., Malmstrom, R. R., and Parker, A.: Standing stocks, production, and respiration of phytoplankton and heterotrophic bacteria in the western Arctic Ocean, Deep-Sea Res. Part II, 56, 1237-1248, 2009a.

Kirchman, D. L., Morán, X. A. G., and Ducklow, H.: Microbial growth in the polar oceans - role of temperature and potential impact of climate change, Nat. Rev. Microbiol., 7, 451-459, $2009 \mathrm{~b}$.

Kirchman, D., Lancelot, C., Fasham, M., Legendre, L., Radach, G., and Scott, M.: Dissolved organic matter in biogeochemical models of the ocean, in: Towards a model of ocean biogeochemical processes, edited by: Evans, G. and Fasham, M., SpringerVerlag, Berlin, 209-225, 1993.

Lavoie, D., MacDonald, R. W., and Denman, K. L.: Primary productivity and export fluxes on the Canadian shelf of the Beaufort Sea: A modelling study, J. Mar. Syst., 75, 17-32, 2009.

Lee, C., Wakeham, S., and Arnosti, C.: Particulate organic matter in the sea: The composition conundrum, Ambio, 33, 565-575, 2004.

Macdonald, R. W., Wong, C., and Erickson, P.: The distribution of nutrients in the southeastern Beaufort Sea: Implications for water circulation and primary production, J. Geophys. Res., 92, 2939 2952, 1987.

Macdonald, R. W., Solomon, S. M., Cranston, R. E., Welch, H. E., Yunker, M. B., and Gobeil, C.: A sediment and organic carbon budget for the Canadian Beaufort Shelf, Mar. Geol., 144, 255273,1998
Manley, T. and Hunkins, K.: Mesoscale eddies of the Arctic Ocean, J. Geophys. Res., 90, 4911-4930, 1985.

Mathis, J. T., Hansell, D. A., and Bates, N. R.: Strong hydrographic controls on spatial and seasonal variability of dissolved organic carbon in the Chukchi Sea, Deep-Sea Res. Part II, 52, 32453258, 2005.

Mathis, J. T., Pickart, R. S., Hansell, D. A., Kadko, D., and Bates, N. R.: Eddy transport of organic carbon and nutrients from the Chukchi Shelf: Impact on the upper halocline of the western Arctic Ocean, J. Geophys. Res.-Oceans, 112, C05011, doi:10.1029/2006JC003899, 2007.

Ogura, N.: Further studies on decomposition of dissolved organic matter in coastal seawater, Mar. Biol., 31, 101-111, 1975.

Ortega-Retuerta, E., Jeffrey, W. H., Babin, M., Bélanger, S., Benner, R., Marie, D., Matsuoka, A., Raimbault, P., and Joux, F.: Carbon fluxes in the Canadian Arctic: patterns and drivers of bacterial abundance, production and respiration on the Beaufort Sea margin, Biogeosciences, 9, 3679-3692, doi:10.5194/bg-9-36792012, 2012.

Pomeroy, L. R. and Deibel, D.: Temperature regulation of bacterial activity during the spring bloom in Newfoundland coastal waters, Science, 233, 359-361, 1986.

Retamal, L., Vincent, W. F., Martineau, C., and Osburn, C. L.: Comparison of the optical properties of dissolved organic matter in two river-influenced coastal regions of the Canadian Arctic, Estuar. Coast. Shelf S., 72, 261-272, 2007.

Retamal, L., Bonilla, S., and Vincent, W. F.: Optical gradients and phytoplankton production in the Mackenzie River and the coastal Beaufort Sea, Polar Biol., 31, 363-379, 2008.

Sakshaug, E.: Primary and secondary production in the Arctic seas, in: The organic carbon cycle in the Arctic Ocean, edited by: Stein, R. and Macdonald, R., Springer-Verlag, Berlin, 57-81, 2004.

Sallon, A., Michel, C., and Gosselin, M.: Summertime primary production and carbon export in the southeastern Beaufort Sea during the low ice year of 2008, Polar Biol., 34, 1989-2005, 2011.

Søndergaard, M. and Middelboe, M.: A cross-system analysis of labile dissolved organic carbon, Mar. Ecol.-Prog. Ser., 118, 283 294, 1995.

Spall, M. A., Pickart, R. S., Fratantoni, P. S., and Plueddemann, A. J.: Western Arctic shelfbreak eddies: Formation and transport, J. Phys. Oceanogr., 38, 1644-1668, 2008.

Springer, A. M. and McRoy, C. P.: The paradox of pelagic food webs in the northern Bering Sea - III, Patterns of primary production, Cont. Shelf Res., 13, 575-599, 1993.

Strom, S. L., Benner, R., Ziegler, S., and Dagg, M. J.: Planktonic grazers are a potentially important source of marine dissolved organic carbon, Limnol. Oceanogr., 42, 1364-1374, 1997.

Thingstad, T. F., Hagstrom, A., and Rassoulzadegan, F.: Accumulation of degradable DOC in surface waters: Is it caused by a malfunctioning microbial loop?, Limnol. Oceanogr., 42, 398-404, 1997.

Uher, G., Hughes, C., Henry, G., and Upstill-Goddard, R. C.: Nonconservative mixing behavior of colored dissolved organic matter in a humic-rich, turbid estuary, Geophys. Res. Lett., 28, 33093312, 2001.

Wallace, D. W. R., Moore, R. M., and Jones, E. P.: Ventilation of the Arctic Ocean cold halocline: rates of diapycnal and isopycnal transport, oxygen utilization and primary production inferred 
using chlorofluoromethane distributions, Deep-Sea Res. Part I, 34, 1957-1979, 1987.

Walsh, J. J., McRoy, C. P., Coachman, L. K., Goering, J. J., Nihoul, J. J., Whitledge, T. E., Blackburn, T. H., Parker, P. L., Wirick, C. D., Shuert, P. G., Grebmeier, J. M., Springer, A. M., Tripp, R. D., Hansell, D. A., Djenidi, S., Deleersnijder, E., Henriksen, K., Lund, B. A., Andersen, P., Mullerkarger, F. E., and Dean, K.: Carbon and nitrogen cycling within the Bering/Chukchi Seas: Source regions for organic matter effecting AOU demands of the Arctic Ocean, Prog. Oceanogr., 22, 277-359, 1989.
Walsh, J. J., Dieterle, D. A., Muller-Karger, F. E., Aagaard, K., Roach, A. T., Whitledge, T. E., and Stockwell, D.: CO2 cycling in the coastal ocean. II. Seasonal organic loading of the Arctic Ocean from source waters in the Bering Sea, Cont. Shelf Res., 17, 1-36, 1997.

Wheeler, P. A., Watkins, J. M., and Hansing, R. L.: Nutrients, organic carbon and organic nitrogen in the upper water column of the Arctic Ocean: implications for the sources of dissolved organic carbon, Deep-Sea Res. Part II, 44, 1571-1592, 1997. 